耐糖能異常を有する原発性肝癌手術症例の検討

\author{
北海道大学第 1 外科 \\ 今野 哲朗 樟本 賢首 白戸 博志 能登 啓光 \\ 柿田章 中西昌美佐野文男内野純一

\section{CLINICAL ANALYSIS OF HEPATIC SURGERY FOR PRIMARY LIVER CANCER WITH GLUCOSE INTOLERANCE} \\ Tetsuro KONNO, Kenju KUSUMOTO, Hiroshi SHIROTO, \\ Hiromitsu NOTO, Akira KAKITA, Fumio SANO \\ and Junichi UCHINO
}

The first department of surgery, University of Hokkaido, school of medicine

索引用語：原発性肝癌, 糖尿病, インスリン分泌能

はじめに

原発性肝癌は肝硬変を合併することが多く, 耐糖能 異常を有する症例をしばしば経験し，その術前・術後 管理が問題となる.今回, 耐糖能異常を有する原発性 肝癌の術前・後術の血糖値变動括よび術後合併症との 関係について検討した。

\section{1. 方法およU対象}

原発性肝癌手術例を, 1970年日本糖尿病学会勧告 値 ${ }^{1)}$ (表 1 ) に従い, $50 \mathrm{~g} ・ \mathrm{O}-\mathrm{GTT}$ において, 空腹時血 糖 $140 \mathrm{mg} / \mathrm{dl}$ 以上, または 1 時間値 $160 \mathrm{mg} / \mathrm{dl}, 2$ 時間値 $130 \mathrm{mg} / \mathrm{dl}$ 以上とともに満たするのを糖尿病域とし， 空腹時血糖 $100 \mathrm{mg} / \mathrm{dl}$ 以下, 1 時間値 $140 \mathrm{mg} / \mathrm{dl}$ および 2 時間值 $100 \mathrm{mg} / \mathrm{dl}$ 以下の全てを満たすすのを正常域 とし, 糖尿病域にも正常域にも属さないるのを境界域 とし 3 群に分けた。

また各症例の $50 \mathrm{~g} ・ \mathrm{OGTT}$ 時の $\Delta \mathrm{IRI} / \Delta \mathrm{BS}^{2)} 30$ 分值, および $\Sigma I R I / \Sigma B S^{3)} 180$ 分値を求めて（表 1 ），インス リン応答能扣よび分泌量を検索し，術後血糖推移扣よ び術後合併症との関係について検討した。

対象症例は1975年から1984年までの10年間に当科で 経験した原発性肝癌手術症例148例のらち検索可能で あった111例である(表 2).

検索症例111例中, 非硬変例は52例で硬変合併例は59 例であった，耐糖能異常例で糖尿病域を示するのは45 例，40.5\%であり，境界域は44例，39.6\%にみられ，

※第26回日消外総会シンボ I : 消化器外科と糖尿病 <1985年11月 12 日受理>別刷請求先：今野 哲朗 干060 札幌市北区北15条西七丁目 北海道大学医学 部第 1 外科
表 1 耐糖能異常の判定基準および検検索項目 1) $50 \mathrm{~g}$ ブドウ糖負荷試験 $(50 \mathrm{~g} \cdot \mathrm{O}-\mathrm{GTT})$

\begin{tabular}{|c|c|c|}
\hline & 正常 域 & 糖尿病域 \\
\hline 架腹時値 & 100L下 & 140 以上 \\
\hline 1 時間値 & 1401E下 & 160 以上 \\
\hline 2 時間値 & $100 \mathrm{LF}$ & 130 以上 \\
\hline
\end{tabular}

2) 検索項目

$50 \mathrm{~g} \cdot \mathrm{O}-\mathrm{GTT} \quad \Delta \mathrm{IRI} / \Delta \mathrm{BS}(30 \mathrm{~mm})$ $\Sigma \mathrm{IRI} / \Sigma \mathrm{BS}$

表 2 耐糖能異常と原発性肝癌手術例

\begin{tabular}{|c|c|c|c|c|c|c|}
\hline \multicolumn{3}{|c|}{ 原発性肝癌手術例 } & \multicolumn{4}{|c|}{ 148例 } \\
\hline \multirow[t]{3}{*}{ " } & " & 検索例 & & & $1975 \sim 198$ & 4年 \\
\hline & \multirow{2}{*}{ 硬変 } & \multicolumn{3}{|r|}{ 糖 } & 能 & \\
\hline & & 糖尿病域 & & 界 域 & 正 常 域 & \\
\hline \multirow{3}{*}{ 全111例 } & $(-)$ & 13 & & 22 & 17 & 52 \\
\hline & $(+)$ & 32 & & 22 & 5 & 59 \\
\hline & & $45(40.5)$ & 4 & $(39.6)$ & $22(19.9)$ & 111 \\
\hline \multirow{3}{*}{ 肝切除例 } & $(-)$ & 9 & & 11 & 10 & 30 \\
\hline & $(+)$ & 29 & & 13 & 3 & 45 \\
\hline & & $38(50.7)$ & & $(32.0)$ & $13(17.3)$ & 75 \\
\hline
\end{tabular}

正常域を示すものは22例，19.9\%であった。

肝切除症例ば75例で, 糖尿病域の耐糖能異常を有す るものは38例，50.7\%にみられ，境界域は24例, $32.0 \%$ で正常域を示するのは13例，17.3\%であった（表 2 ）。

\section{II. 成 績}

1. 耐糖能異常例の術前・術後血糖値 
表 3 糖尿病域耐糖能異常と空腹時血糖值

\begin{tabular}{|c|c|c|c|c|c|c|}
\hline \multirow[b]{2}{*}{ 硬変 } & \multirow{2}{*}{$\begin{array}{l}\text { 情尿病域 } \\
\text { 症 例 }\end{array}$} & \multirow[b]{2}{*}{ 空腹時血糖値 } & \multirow[b]{2}{*}{ 症 例 } & \multicolumn{2}{|c|}{$\Delta \mathrm{IRI} / \Delta \mathrm{BS}$} & \multirow{2}{*}{$\begin{array}{l}\text { 糖尿病域 } \\
\text { 耐糖能異常 }\end{array}$} \\
\hline & & & & $\underset{25}{0.5 \text { 以下 }}$ & $\underset{27}{0.5 \text { 以上 }}$ & \\
\hline \multirow{4}{*}{$\begin{array}{c}(-) \\
52\end{array}$} & \multirow{3}{*}{$13(25.0)$} & $<100$ & 42 & 3 & 3 & 6 \\
\hline & & $100 \leqq<140$ & 9 & 6 & 0 & 6 \\
\hline & & $>140$ & 1 & 1 & 0 & 1 \\
\hline & & & & 32 & 27 & \\
\hline \multirow{3}{*}{$\begin{array}{c}(+) \\
59\end{array}$} & \multirow{3}{*}{$32(54.2)$} & $<100$ & 41 & 10 & 6 & 16 \\
\hline & & $100 \leqq<140$ & 16 & 10 & 4 & 14 \\
\hline & & $>140$ & 2 & 2 & 0 & 2 \\
\hline 111 & $45(40.5)$ & & & & & \\
\hline
\end{tabular}

表 $4 \Delta \mathrm{IRI} / \Delta \mathrm{BS}$ と血糖血

一術当日最高血糖値 $300 \mathrm{mg} / \mathrm{dl}$ 以上例一

\begin{tabular}{|c|c|c|c|c|c|}
\hline \multirow{2}{*}{$\Delta \mathrm{IRI} / \Delta \mathrm{BS}$} & \multirow{2}{*}{ 䀒 切 除 } & \multicolumn{2}{|c|}{ 硬変 } & \multirow{2}{*}{\multicolumn{2}{|c|}{ 最高血糖值 $300 \mathrm{mg} / \mathrm{dl}$ 以上 }} \\
\hline & & $(-)$ & $(+)$ & & \\
\hline$<0.2$ & $\begin{array}{l}\text { 旰切なし } \\
\text { " } 1 \text { 区域以下 } \\
\text { " } " \text { 以上 }\end{array}$ & $\begin{array}{l}0 / 3 \\
0 / 3 \\
3 / 3\end{array}$ & $\begin{array}{l}0 / 14 \\
7 / 14 \\
3 / 14\end{array}$ & $\left.\begin{array}{l}0 / 17 \\
7 / 17 \\
6 / 17\end{array}\right\}$ & $13 / 17(76.5)$ \\
\hline \multirow[t]{2}{*}{$>0.2$} & $\begin{array}{l}\text { 肝切なし } \\
\text { "1区域以下 } \\
" \text { " } 1 \text { 以上 }\end{array}$ & $\begin{array}{l}0 / 15 \\
0 / 15 \\
2 / 15\end{array}$ & $\begin{array}{l}0 / 24 \\
6 / 24 \\
5 / 24\end{array}$ & $\left.\begin{array}{l}0 / 39 \\
6 / 39 \\
7 / 39\end{array}\right\}$ & $13 / 39(33.3)$ \\
\hline & & $\begin{array}{c}5 / 18 \\
(27.7)\end{array}$ & $\begin{array}{c}21 / 38 \\
(55.3)\end{array}$ & & $\begin{array}{l}26 / 56 \\
(46.4)\end{array}$ \\
\hline
\end{tabular}

糖尿病域を示す耐糖能異常例について検討すると (表 3), 非硬変52例中13例, $25.0 \%$ であるのに対し, 硬変例では59例中 32 例, $54.2 \%$ と半数以上に糖尿病域 の耐糖能異常を示した。

入院時の空腹時血糖において, $100 \mathrm{mg} / \mathrm{dl}$ 以上と正 常值を示すものは，非硬変例では42例で，そのうち 6 例, $14.3 \%$ に耐糖能異常を認め, 硬变例では 41 例が 100 $\mathrm{mg} / \mathrm{dl}$ 以下で, そのうち16例， $39.0 \%$ に耐糖能異常を 認めた.

インスリン初期分泌応答能を表わす $\Delta \mathrm{IRI} / \Delta \mathrm{BS} 30$ 分值に扔いて， $\Delta$ 比 0.5 以下4)のものは非硬変例で25 例, $48.1 \%$, 硬変例では 32 例， $54.2 \%$ 之原発性肝癌 症例の半数にインスリン分泌応答能異常を認めた。 入 院時空腹時血糖値と $\Delta \mathrm{IRI} / \Delta \mathrm{BS}$ との関係をみると, 比 0.5 以上のものは全例空腹時血糖値 $140 \mathrm{mg} / \mathrm{dl}$ 末满 であった。

次に術当日の術後血糖値変動検索可能例の56例につ いて, 血糖值 $300 \mathrm{mg} / \mathrm{dl}$ 以上例を調べてみると(表 4 ), 非硬変例の $27.7 \%$, 硬変例では $55.3 \%$ に $300 \mathrm{mg} / \mathrm{dl}$ 以上の高血糖值を示した. $\Delta$ 比 0.2 以下では $76.5 \%, \Delta$ 比 0.2 以上では $33.3 \%$ に高血糖値を示した。従って術前
$\Delta$ 比 0.2 以下の症例に術後インスリン使用の必要性が 示唆される。

2. 酎糖能異常々合併症

合併症例の内訳を表 5 に示した。イレウス，心筋梗 塞を除いては，糖尿病による合併症というよりは肝機 能低下による合併症と考えられる。

合併症と $\Delta \mathrm{IRI} / \Delta \mathrm{BS}$ との関係をみると, 非硬変例 52 例に打いて(表 6$)$, 糖尿病域耐糖能異常例のうち, 5

\section{表 5 耐糖能異常之合併症} 一糖尿病域の合併症内訳一

\begin{tabular}{|c|c|c|}
\hline 合 併 症 & 硬変 $(+)$ & 便多 $(-)$ \\
\hline $\begin{array}{l}\text { 呼吸不全 } \\
\text { 肝不全 } \\
\text { 消化管出血 } \\
\text { 術後出血 } \\
\text { 食道静脈瘤出血 } \\
\text { 腹 水 } \\
\text { イレゥス } \\
\text { 心筋硬塞 }\end{array}$ & $\begin{array}{l}\text { (肝切) } \\
2(2) \\
1(1) \\
3(2) \\
3(2) \\
2(2) \\
3(3) \\
1(1)\end{array}$ & $\begin{array}{l}2(2) \\
1(0) \\
1(1)\end{array}$ \\
\hline & 15 (13) & $5(4)$ \\
\hline
\end{tabular}


例に合併症をみるが，いずれも $\Delta$ 比が 0.2 以下のもの であった。ささらに境界域も含めて検討すると， $\Delta$ 比 0.2 以下は $50.0 \%$ に $\Delta$ 比 0.2 から0.8の間には $27.3 \%$ に合 併症をみ， $\Delta$ 比 0.8 以上には合併症をみなかった。

一方, 糖尿病域の合併症発生は38.5\%, 境界域は $18.2 \%$ ，正常域は $11.8 \%$ と少なくなる。すなわち非硬 变例では, $\Delta$ 比が小さい值を示すすのほど,また耐糖能 異常が糖尿病域に近づく汪ど合併症発生が多くなる。

非硬変, 肝切除例に打いて子(表 6 ), 糖尿病域 9 例 中 4 例に合併症が生じ， 4 例とも $\Delta$ 比 0.2 以下のあの であり，同様な傾向を示した。

次に硬变合併例に括ける合併症と $\Delta \mathrm{IRI} / \Delta \mathrm{BS}$ との 関係をみると(表 7)，糖尿病域を示す症例の合併症は $46.9 \%$ であ. 万ち $\Delta$ 比 0.5 以下は $47.8 \%, \Delta$ 比 0.5 以
上は $44.4 \%$ に合併症をみている. 肝切除例に限ると, 糖尿病域を示寸症例のうち, 合併症は $\Delta$ 比0.5以下で $47.6 \%, \Delta$ 比 0.5 以上で $37.5 \%$ に発生している.

以上, 硬変合併例は $\Delta \mathrm{IRI} / \Delta \mathrm{BS}$ と合併症例数との相 関関係は薄いが，これは硬変例では，非硬变例と異な ク, 肝機能低下例が大部分を占め, 合併症発生に肝機 能低下が影響をおよぼしているためと考えられる。

そこで, 糖尿病域および境界域の耐糖能異常を伴う 肝癌切除症例を, 糈軸に ICG Rmax, 横軸に $\Delta \mathrm{IRI} /$ $\triangle \mathrm{BS}$ をプロットした図表にあてはめてみた（図 1)。 ICG Rmax が0.8以上と肝機能良好であるにもかかわ らず合併症例をみるが，これらは $\Delta$ 比が 0.2 以下の領 域に多く, $\Delta$ 比 0.8 以上では 1 例を除き合併症をみな い.

表 6 耐糖能異常々合併症例 $-\Delta \mathrm{IRI} / \Delta \mathrm{BS}$ との関係-

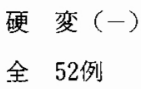

\begin{tabular}{|c|c|c|c|c|}
\hline$\Delta \mathrm{IRI} / \Delta \mathrm{BS}$ & 糖尿病域 & 境界 域 & & 正 常 域 \\
\hline$<0.2$ & $5 / 8$ & $1 / 4$ & $6 / 12(50.0)$ & \\
\hline $0.2 \leqq<0.8$ & $0 / 2$ & $3 / 9$ & $3 / 11(27.3)$ & \\
\hline \multirow[t]{2}{*}{$\geqq 0.8$} & $0 / 3$ & $0 / 9$ & $0 / 12(0)$ & \\
\hline & $5 / 13(38.5)$ & $4 / 22(18.2)$ & $9 / 35(25.7)$ & $2 / 17(11.8)$ \\
\hline$\Delta \mathrm{IRI} / \Delta \mathrm{BS}$ & 糖尿病院 & 境界 域 & & 正 常 域 \\
\hline$<0.2$ & $4 / 7$ & $0 / 0$ & $4 / 7(57.1)$ & \\
\hline $0.2 \leqq<0.8$ & $0 / 1$ & $3 / 5$ & $3 / 6(50.0)$ & \\
\hline \multirow[t]{2}{*}{$\geqq 0.8$} & $0 / 1$ & $0 / 6$ & $0 / 7(0)$ & \\
\hline & $4 / 9(44.4)$ & $3 / 11(27.3)$ & $7 / 20(35.0)$ & $2 / 10(20.0)$ \\
\hline
\end{tabular}

表 7 耐糖能異常と合併症例 $-\Delta \mathrm{IRI} / \Delta \mathrm{BS}$ との関係一

硬 変 $(+)$

全 59例

\begin{tabular}{|c|c|c|c|c|}
\hline$\Delta \mathrm{IRI} / \Delta \mathrm{BS}$ & 糖尿病域 & 境 界 域 & & 正 常 域 \\
\hline $\begin{array}{c}<0.2 \\
0.2 \leqq<0.5\end{array}$ & $\left.\begin{array}{l}6 / 14 \\
5 / 9\end{array}\right)(47.8)$ & $\left.\begin{array}{l}0 / 4 \\
4 / 11\end{array}\right)(26.7)$ & $\left.\begin{array}{l}6 / 18 \\
9 / 20\end{array}\right)(39.5)$ & \\
\hline \multirow[t]{2}{*}{$\begin{array}{c}0.5 \leqq<0.8 \\
>0.8\end{array}$} & $\left.\begin{array}{ll}4 / 6 \\
0 / 3\end{array}\right)(44.4)$ & $\left.\begin{array}{ll}0 / 2 \\
1 / 5\end{array}\right)(14.3)$ & $\left.\begin{array}{ll}4 / & 8 \\
1 / & 8\end{array}\right)(31.3)$ & \\
\hline & $15 / 32(46.9)$ & $5 / 22(22.7)$ & $20 / 54(37.0)$ & $0 / 5(0)$ \\
\hline
\end{tabular}

肝切除 45例

\begin{tabular}{|c|c|c|c|c|}
\hline $\begin{array}{c}<0.2 \\
0.2 \leqq<0.5\end{array}$ & $\left.\begin{array}{l}5 / 13 \\
5 / 8\end{array}\right)(47.6)$ & $\left.\begin{array}{ll}0 / & 1 \\
3 / & 6\end{array}\right)(42.9)$ & $\left.\begin{array}{l}5 / 14 \\
8 / 14\end{array}\right)(46.4)$ & $0 / 3$ \\
\hline $\begin{array}{c}0.5 \leqq<0.8 \\
>0.8\end{array}$ & $\left.\begin{array}{ll}3 / & 5 \\
0 / & 3\end{array}\right)(37.5)$ & $\left.\begin{array}{ll}0 / & 2 \\
0 / & 4\end{array}\right)\left(\begin{array}{ll}0 & 0\end{array}\right)$ & $\left.\begin{array}{l}3 / 7 \\
0 / 7\end{array}\right)(21.4)$ & \\
\hline & $13 / 29(44.3)$ & $3 / 13(23.1)$ & $16 / 42(35.7)$ & $0 / 3(0)$ \\
\hline
\end{tabular}


図 1 耐糖能異常例の肝切除之合併症 -ICG Rmax との関係-

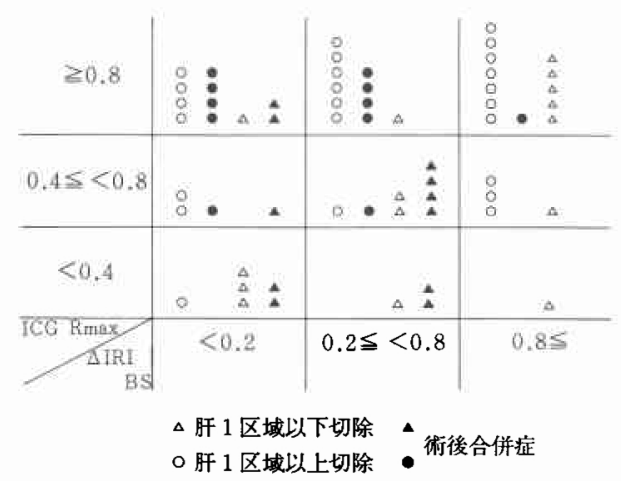

図 2 肝切除之街後合併症例 ICG Rmax と $\mathrm{\Sigma IRI} / \mathrm{BS}$ との関係

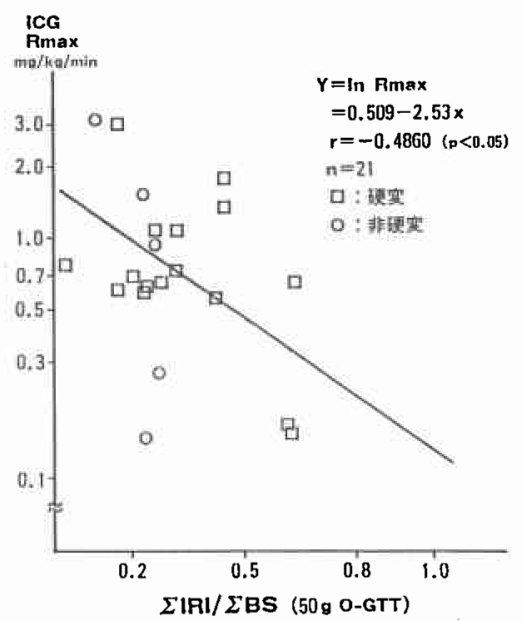

次に肝切除例の合併症例に限り, 緃軸に ICG Rmax の対数，横軸に $\Sigma \mathrm{IRI} / \Sigma \mathrm{BS}^{3)}$ をプロットした図表にあ てはめてみると, 合併症例の ICG Rmax と $\Sigma$ IRI/ $2 B S$ は0.05\%以下の危険率で逆相関関係を示した（図 2 ）.

\section{III. 考 案}

耐糖能異常を伴った肝癌手術症例を検討すると，肝 機能低下に由来すると考えられる合併症が多いが，こ れはエネルギー代謝を介して肝予備力の低下によると 考兄られる. 肝臓手術, とりわけ肝切除後は, 残存肝 に代謝的負荷がかかっている時点であるが，それに対 処するため, 肝ミトコンドリアのATP 生成能は代償 的に元進する。.その元進は門脈内インスリンの増加に
よって生ずるが5)，インスリン分泌能低下があると、こ の代償的充進が不十分なため, 肝の機能的予備力の低 下がひき起される，ところが，耐糖能異常でひき起さ れるこの予備力の低下は，ICG Rmax などの一般的肝 機能検查には反映されない肝の機能異常を示している と言える。

耐糖能と肝機能予備力の研究にお括て, 小沢らは5), OGTTによる血糖曲線が energy charge を反映する とし, 血糖曲線の解析 (parabolic 型か linear 型か)が, 肝の予備能判定に有効と報告している。 また平良ら は6), OGTTに扣いてインスリン分泌動態を反映する

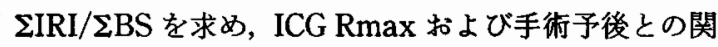
俰を検討し, 肝切除例の耐糖能異常群では ICG Rmax と $\mathrm{IIRI} / \Sigma \mathrm{BS}$ の間に負の相関を認め, これら二つの検 查によって肝切除の適応判定が可能としている.

今回, 同様な検討を加えたが，母集団を肝切除例の

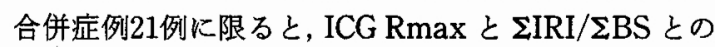
間に逆相関関係が認められ，一般肝機能検查の他に $\Sigma I R I / \Sigma B S$ は肝予備能の評価に有用と考号られた。

\section{IV. 結 論}

1. 原発性肝癌手術症例に打いて, 入院時空腹時血糖 値が正常なものでも OGTT において多く耐糖能異常 を認めた。

2. 糖㽷病域の耐糖能異常を示寸症例は $40 \%$ と多く, また $\Delta \mathrm{IRI} / \Delta \mathrm{BS} 0.5$ 以下のインスリン分泌低下例も半 数にみられた。

3. 肝機能予備能の判定に打いて, 従来の肝機能検査 による方法のほかに $\Delta \mathrm{IRI} / \Delta \mathrm{BS}, \mathrm{IIRI} / \Sigma \mathrm{BS}$ 測定によ るインスリン分泌能の検査が有用である.

\section{文 献}

1）葛西信貞, 阿部正和, 上田英雄仿加：糖負荷試験に おりる糖尿病診断基準委員会報告。糖尿病 13 ： $1-7,1970$

2) Seltzer HS, Allen EW, Herron AL et al: Insulin secretion in response to glycemic stimulus : Relation of delayed initial releasle to carbohydrate intolerance in mild diabetes mellitus. J Clin Invest $46: 323-335,1967$

3）阿南郷一郎：慢性肝疾患に打ける耐糖能異常 -ICG 排泄試験からみた腇機能障害度とインスり ン分泌一。滋恵医大誌 $91: 380-394 ， 1976$

4）金井 泉：憎内分泌負荷試駼. 金井正光編, 臨床検 查法提要, 第29版, 東京, 金原出版, 1983, p625-629

5）小澤和恵, 木村健一, 浅野元和滍力：肝機能予備力 の評価一機能面から：エネルギー代謝一。肝胆膵 $3: 815-819,1981$

6）平良健康, 及野健一, 樟本蜸首法加：肝切除耐術能 の判定一血中インスリン糖面積比 (GTT) 之 ICG $R \max$ の相関. 肝臓 $21: 273,1980$ 